\title{
Nomads, "Gypsies," and Criminals in England and India from the Seventeenth to the Nineteenth Century
}

\section{Cristina-Ioana Dragomir}

cid2102@columbia.edu

Institute for the Study of Human Rights, Columbia University

ORCID: https://orcid.org/0000-0001-7674-731X

Cristina-Ioana Dragomir teaches at the Institute for the Study of Human Rights at Columbia University. Employing a critical feminist perspective, her work navigates the fields of social justice, human rights, subaltern studies, immigration, and citizenship. She received her $\mathrm{PhD}$ from the New School for Social Research in Politics. Using a transnational framework, she analyzes the processes employed by Roma and Adivasi communities to mobilize against racial and ethnic discrimination in Europe and India, and she describes the practices and processes these groups use to challenge the existing political and social order, and how they strive to achieve parity.

\section{Critical}

Romani Studies 


\section{Abstract}

Both across Europe and India many mobile groups frequently are labeled as "Gypsy" and often are referred to as "criminals." Employing a critical approach, this article unveils how the intersection of nomadism, the "Gypsy" label, and criminality was not a "natural" occurrence, but one that came about through legal and literary discourses that have been used systematically since the seventeenth century. The connection between nomadism and criminality has been investigated both in Europe (Mayall 1988; Lucassen 1997; Lucassen and Willems 2003; Bardi 2006; Nord 2008) and in India (Radhakrishna 2001, 2009; Piliavsky 2015). These bodies of work are valuable as they examine how criminalization of groups took place. This article builds on this existing scholarship, and focuses its comparative investigation on several of the dominant discourses in England and India from the seventeenth to the nineteenth century. However, it is different from previous work on three accounts. First, it engages critically with the "Gypsy" label and details how this categorization became connected both with nomadism and criminality. Second, it claims that the criminalization of those who move in India preceded British colonial rule. Thus, it highlights how similar forms of community criminalization took place both in England and India. Third, this article argues that both legal and literary discourses are techniques through which power operates, and therefore analyzes the development of nomadism, criminality, and the "Gypsy" label within these interconnected mediums.

\section{Keywords}

- Roma

- "Gypsy"

- Nomadism

- Criminality

- England

- India 


\section{Introduction: The Intersectionality of Mobility, Criminality, and Ethnicity}

Our identity is socially constructed. Who we are and how we define ourselves takes place through a complex interactionist process (Conrad and Schneider 1992) in which others categorize us, and we also categorize ourselves. Both our individual and community identities are born out through such dialogical acts, which are based on particular uses of language, discourses, and modes of expression (Taylor 1994, 34). Thus, if identities are constructed in relation to others, we need to understand how others see, describe, and potentially objectify people's identity. Moreover, as identities are constructed within power systems, we need to carefully examine how those in power classify and (il)legalize those whose access to power is more limited than theirs.

The present article does not aim to look at the complexity of identity formation, but aims to reveal how the intersection of categorizing communities as "nomad," "criminal," and "Gypsy" ${ }^{[1]}$ lead to the criminalization of those labeled as "Gypsy." Specifically, I will bring into view how these labels became institutionalized. As these categorizations are not "created instantaneously" (Berger and Luckmann 1967, 72), following Conrad and Schneider (1992), I will outline the historical dimension of this process. I start from the assumption that if deviance and criminality are "social definitions," then we need to analyze how they come into being and how they become attached to and associated with particular groups of people (Conrad and Schneider 1992, 2)

The time period researched for this article spans the seventeenth to the nineteenth century. While the above-mentioned labels were in use before the seventeenth century and until today, focusing on this period allows us to see the emergence of both legal and literary discourses that focused and crystallized the criminalization of those who move, while identifying them as "Gypsies." Also, due to the colonial links between the United Kingdom and India during this period, we can trace how these categorizations traveled and were adapted to existent local societal structures. Thus, while this intersection of the three labels took place in many European countries around the same period of time, ${ }^{[2]}$ this article focuses only on England and India, where we see draconian forms of criminalization of those who move and who were simultaneously identified as "Gypsy."

1 Individuals and communities labeled as "Gypsy" have been thought to originate in India. This article does not intend to demonstrate the Indian origin of those named "Gypsy" or to add anything to that particular conversation. For more information, see: Shashi 1990; Crowe 1994/1996; Fonseca 1995/2006; Barany 2002; Matras 2014/2015; Surdu 2017.

2 This is not to say that all nomads were regarded as criminals or "Gypsies," or that all those categorized as criminals were nomads. Rather, I argue that these labels were quite flexible and interpenetrated, creating a systematic criminalization of those who move from territory to territory, a legacy still experienced today. Moreover, not all European traveling communities were treated equally. While most of the European nomadic groups were targeted by legislation attempting to curve their mobility, at times law enforcement agencies were more lenient with the Irish travellers, the Yenish, or the carnival people who somehow were accommodated at the margins of society. Similarly, in India, spiritual seekers (sadhus) and pastoral communities were not criminalized but accepted and even held in high social esteem in some instances. 
The connection between nomadism and criminality has been investigated both in Europe (Mayall 1988; Lucassen 1997; Lucassen and Willems 2003; Bardi 2006; Nord 2008) and in India (Radhakrishna 2001, 2009; Piliavsky 2015), but the two bodies of scholarship were not placed in comparison so as to highlight the common modes of criminalization in each context. This article aims to fill this gap and to start a process of comparative analysis of the criminalization of particular communities in both South Asia and European countries. ${ }^{[3]}$

This article starts by outlining the methodology and the historical context of nomadism and the state, and then proceeds by outlining the legal system in regards to nomadism and the "Gypsy" label in England and then in India. The final part will follow the same structure, and starts by outlining common tropes within the English literature and then moves on to show several comparable literary discourses in India. This structure was chosen to facilitate the reading of the sources and to highlight in each case the main points that have contributed to the process of criminalization of those who move and are labeled as "Gypsy."

This article is not intended as an exhaustive work. Quite the contrary, I focus on highlighting the identity construction process by looking at several legal and literary discourses in England and India from the seventeenth to the nineteenth century. In doing so I outline how typically unrecognized power operates within society (Taylor 2015,3). The primary aim of this article is to enable rigorous and in-depth conversations and research into the criminalization of groups labeled as "Gypsy" ${ }^{[4]}$ in order to disrupt what others take for granted or see as "normal" (ibid.) regarding the criminalization of Roma and Adivasi communities.

\section{Methodology}

Because the goal is to compare discourses developed on two continents that are united by a shared history of colonial power, this work uses legal documents and original sources. However, it also relies on secondary sources, especially works that outline trends within the discourses of the time. I use these bodies of literature as a springboard to further parallel discourses that reveal the construction of nomadism and criminality in relation to the "Gypsy" label.

Considering the presence of nomadic communities both in England and India (and beyond), ${ }^{[5]}$ as well as their historical colonial connection, this comparative discourse analysis exposes the underpinnings

\footnotetext{
3 While focusing on India and England for this article, over fifty primary and secondary sources were surveyed. I also additionally consulted literature on the Netherlands, France, Romania, and Russia. This article looks at the historical development of different discourses in England although a similar situation can be observed in other European countries as well. See, for example, Jan Lucassen and Leo Lucassen 1997.

4 The term "Gypsy" is a historically constructed term (Surdu 1984). Since the sixteenth century, the term has been used to define multiple communities and subcommunities, all of which speak different languages and/or diverse Romani dialects; they have different religions, lands, histories, and cultures. Due to its complicated history, the "Gypsy" label is a politically loaded term and its negative connotations overwhelmingly outweigh its positive categorization (Matache 2017). To acknowledge these difficulties and their implications, I will place the term in quotes.
}

5 For more on nomads and the state in the Near East, see Szuchman 1984. 
of the ways in which certain mobile communities, especially those labeled as "Gypsies," were regarded between the seventeenth and the nineteenth century. This article starts from a basic assumption: laws and regulations are not enacted in vacuums; they are deeply rooted in their historical contexts, and as a result it is necessary to investigate both the legal and literary discourses that referred to criminality, nomadic lifestyle, and the "Gypsies." This view is based on Michel Foucault's text (1977/1997), which argues that in order to understand how power operates we need to investigate its dispositif:

Thoroughly heterogeneous ensemble consisting of discourses, institutions, architectural forms, regulatory decisions, laws, administrative measures, scientific statements, philosophical, moral and philanthropic propositions - in short, the said as much as the unsaid. (...) Between these elements, whether discursive or non-discursive, there is a sort of interplay of shifts of position and modifications of function which can also vary very widely (Foucault 1977/1997, 194).

The present article uses a genealogical exploration of the dispositif at work in both England and India during the time when England exercised great influence into its Indian colonies. By "genealogical exploration," I mean that I am employing an analytical method that targets discourses rather than individuals. This approach exposes acclaimed ideas and embedded practices and aims to reveal how both knowledge is constituted and how categorizations are created.

Foucault described genealogy as "gray meticulous, and patiently documentary. It operates on a field of entangled and confused parchments, on documents that have been scratched over and recopied many times" $(2001,139)$. From this often separate account of the past, genealogy seeks in "the most uncompromising places, in what we tend to feel is without history" (Foucault 2001, 140). It understands that that "historical beginnings are lowly," (ibid. 143) not uncovering a divine birth, or "a timeless and essential secret, but the secret that they [i.e., events/ concepts] have no essence or that their essence was fabricated in a piecemeal from alien forms" (ibid. 142). This genealogical approach aims to denaturalize what otherwise appears as natural and immutable, to open up new understandings of mobile communities by unveiling the discursive mechanisms that lead to a systematic criminalizing of those who move, particularly those labeled as "Gypsy."

\section{The State and Nomadism}

As Michel Foucault (1983) argues, during the seventeenth century the European penal system took action whenever central administration or monarchical power wanted to get rid of someone. Prisons had two roles: to exert the power of the state and to organize society in a functional manner. Prior to the eighteenth century, prisons were the symbol of a state's arbitrariness and useful for punishing elements

6 I do not mean to imply that those who were labeled as "Gypsy" were passive and absorbed these discourses and their discriminatory consequences without engaging in different forms of resistance. It is my understanding that communities labeled as "Gypsy" always have employed a variety of practices of direct and indirect resistance. 
disobeying its power. Starting with the eighteenth century, when a new penal code was constructed, prisons became the main form of punishment as well as a form of rehabilitation. Among those who were under systematic scrutiny, starting with the seventeenth century, were those who moved from place to place, thereby eluding the power of the state. Because monarchical and other central administrative powers wanted to exert control over the people living within their territory, those who transgressed were seen both as a threat to power and as a functional problem. ${ }^{[7]}$

According to Lucassen and Lucassen (1997), the rise of the modern state was characterized by direct rule over its people through the organized police, who, as a result, targeted traveling groups and those labeled as "Gypsies." This led to the "stigmatization of the Gypsies (...) because of their visible travelling way of life [that] underlined their status as 'masterless' men, which made them a threat to a well ordered society" (Lucassen and Willems 2003, 10). Mobility especially was controlled and punished in England; furthermore, through British colonial rule many of the techniques of assigning criminality to nomads were exported to and implemented in India, applying these structures onto preexisting methods of criminalization.

\section{Legal System: England from 1600s to 1800 s}

From the seventeenth century onwards, the English state manifested increased interest in controlling "vagabondage," "homelessness," and "vagrancy." ${ }^{[8]}$ People performing these acts were seen as "undesirables" defying the power of the state and were punished as a result. Those labeled as "Gypsy" were among those most frequently disciplined for their habits. Across Europe they were included in decrees that "increasingly regarded [them] as the most dangerous subgroup and [thus they] became the symbol for the unwanted itinerant" (Lucassen and Willems 2003, 10). This was the case as early as 1555, with the Philip and Mary Act, titled An Act against Certain Persons Calling Themselves Egyptians, ${ }^{[9]}$ and which aimed to control the life of those identified as "Egyptians" or "Gypsies":

All and every person and persons (...) in any company or fellowship of vagabonds, commonly calling themselves Egyptians, or counterfeiting, transforming, or disguising themselves by their apparel, speech, or other behaviour, like unto such vagabonds, commonly called or calling themselves Egyptians, and so shall do or continue and remain in the same, either at one time or several times, by the space of one month: that then the said person or persons,

\footnotetext{
7 For more information about the criminalization of nomadism and poverty in the 1600s, see Fishman (2007), and https://eh.net/ encyclopedia/english-poor-laws.

8 Following Geremek (1974), Lucassen (1997) tells us that "the first use of the term 'vagabond' took place in France around 1350 and had a negative connotation signifying 'undesirable wandering behavior," and vagrancy soon came to be considered a crime in itself (Lucassen 1997, 227).

9 According to Crow (1994/1996), Fonseca (1995/2006), and Matras (2014), “Gypsy” comes from the word "Egyptian," and it is based on the myth that mistakenly assumed that Roma groups came from Egypt. For more on Roma's presumed foreign origin, see the second part of this article and also Morgan (2016).
} 
shall by virtue of this act be deemed and judged a felon and felons; and shall therefore suffer pains of death, loss of lands and goods, as in cases of felony by the order of the common laws of this realm (cited in Pickering 1763, 211).

Also, the Act for the Punishment of Vagabonds, and for Relief of the Poor and Impotent (Vagabond Act) of 1572 criminalized groups of "masterless men," such as "all fencers, bearwards, common players of interludes, and minstrels (not belonging to any baron of this realm, or to any other honourable person of greater degree), wandering abroad without the license of two justices at the least" who, as a result of their transgressions, were "grievously whipped and burned through the gristle of the right ear with a hot iron of the compass of an inch about."

The English state of the seventeenth century created the Settlement Act of 1662, which detailed that those who move from place to place had to have with them a Settlement Certificate that would mention their belonging to a parish, which would be responsible for them in case they needed removal (An Act for Better Relief of the Poor of this Kingdom, also known as the Settlement and Removal Act of 1662). In this way the state empowered parishes to further control the population on its territory. To encourage settlements and to prevent those who move to turn into "incorrigible Rogues," the state allowed those settling into one place for more than forty days to apply for "poor relief." The Act further stated that authorities were entitled to move newcomers to their previous settlement if they deemed it necessary. While the Act details the particulars of settlement and removal, it also lays the foundation of an allencompassing paradigm that assumed being settled as the rule. This assumption transformed mobile persons into exceptions to be systematically controlled and punished. ${ }^{[10]}$

Authorities were aware of the distinction between vagrants, vagabonds, and "Gypsies," but placed them under the same law, thus blurring legal differences. The state aimed to limit the mobility of undesirable groups and assert its authority onto their lives, bodies, and goods by using these acts to legally intersect the category of "Egyptian" or "Gypsy" with vagabond. This legal intersection made those who were mobile and those identified as such (who might not have in fact been mobile) into an offense to the state and to its laws. Thus, the state could now legally control the movement of those labeled as "Gypsies."

While the seventeenth century was marked by the state's aim to control movement, in the eighteenth century the state changed its techniques to control and reform "vagrants" under the guise of transforming them into productive citizens. Once apprehended, those deemed as "vagabonds" were punished with public whippings and incarcerated in houses of correction (Lambert 1868). Moreover, they were forced to perform six months of hard labor for the state. By this point, the state developed a preoccupation with rehabilitation, as the law did not seek only to limit mobility and regulate behavior but to remake its subjects, enabling their participation in the doings of (and according to the will of) the state.

10 As concern regarding nomadism was generated within sedentary society, new theories of sedentarism started to take shape, aiming to normalize and produce sedentary models of existence and pathologies and regress nomadic modes of existence (McVeigh 1997, 9) 
These eighteenth-century legislative decisions criminalized behavior by creating a taxonomy, that is, by naming groups that became categories of criminals according to the law. While this taxonomy referred to "vagrants" and "vagabonds," it also included "Egyptians," according to the General Index to the Journals of House of Lords 20-60 Geo III, Vols. XXXVI-LII. ${ }^{[11]}$ For example, with the Vagrancy Act of 1744, people become "vagrants" because of their mobility, their moral characteristics, or their occupational categories. Moreover, they also became criminals simply because of their identification as "Gypsy," as the act declared "vagrants" as "all Persons pretending to be Gypsies, or wandering in the habit or form of the Egyptians." Thus, the 1744 Act established the group criminalization of all who were "pretending" to be "Gypsy," as well as of those who behaved in a manner that was perceived to be alike those labeled "Gypsy." This legal categorization blurred the line between those who identified themselves as "Gypsy" and those who displayed similar behavior, making both groups into criminals. This lack of legal distinction between the two placed those identified as "Gypsy" or "Egyptians" under the same law as "vagabonds" and "vagrants," implicitly linking the former to nomadism and criminality.

Moreover, with the Vagrancy Act of 1744, the English state aimed to reform both those identified as "Gypsies" and "vagabonds." For example, the city or state assigned those labeled "Gypsies" special places to live. In an attempt to restrict their movement and modify their behavior, the state instituted punishments: imprisonment, fines, and corporal punishments like whippings, to name a few. In turn, these measures placed mobile communities next to local authorities in charge of policy implementation, where their behavior could be changed so they could become "useful" for the state.

These judicial discourses helped cement the criminalization of those who were not settled and those labeled as "Gypsies." By the nineteenth century these categories came under further scrutiny. Thus, the Vagrancy Act of 1824 named "vagabonds" as those who were resisting their apprehension as "incorrigible rogues":

Every person apprehended as a rogue and vagabond, and violently resisting any constable or other peace officer so apprehending him or her, and being subsequently convicted of the offence for which he or she shall have been so apprehended; shall, be deemed an incorrigible rogue within the true intent and meaning of this Act (Vagrancy Act of 1824, V: 700).

Just like in its previous formats, in addition to criminalizing those who move, the Act of 1824 paid particular attention to groups whose characteristics overlapped with the people they identified as having "Gypsy" characteristics, such as those people working as fortune tellers or living in mobile homes:

Every Person pretending or professing to tell Fortunes, or using any subtle Craft, Means, or Device, by Palmistry or otherwise, to deceive and impose on any of His Majesty's Subjects; every Person wandering abroad and lodging in any Barn or Outhouse, or in any deserted or unoccupied Building, or in the open Air, or under a Tent, or in any Cart or Waggon, not

11 "Egyptians" were mentioned directly in: "Bill 23 Geo. 3. to repeal 5 Eliz. for further Punishment of Vagabonds so calling themselves; from H.C.; and read l a, xxxvi. 686 a. 2 l, and committed, 692 a. House in Committee, and Bill reported, 693.” 
having any visible Means of Subsistence, and not giving a good Account of himself or herself ... [were] become forfeited to the King's Majesty (Vagrancy Act of 1824 IV: 699-700).

While the Act of 1824 does not refer directly to the "Gypsy" by name, it listed characteristics associated with being a "Gypsy" prevalent in the literature of the time (as we will see next), such as having supernatural powers, fortunetelling, living in the wilderness, and traveling in carts or wagons.

Legal reference and criminalization of those thought to be a "Gypsy" reverberated further into local legislation. For example, in Norfolk, magistrates passed a resolution that referred specifically and solely to "Gypsy" mobile groups: "All persons pretending to be Gypsies or wandering in the habit or form of Egyptians, are by law deemed to be rogues and vagabonds, and are punishable by imprisonment and whipping" (Mayall 1988, 151-2). It determined that "the Gypsies" could be sent to prison "without being charged with transgression" (ibid.).

The striking aspect of these regulations is that they overlook individual responsibility and deem as criminal any person belonging to the "Gypsy"/nomad groups. Laws are understood to be universal and individually applied. However, belonging to a group/community and specifically being identified as a "Gypsy" took away individual application of the law and made entire groups fall under the criterion of criminality.

Thus, from the seventeenth to the nineteenth century, the legal system gradually increased language that referenced nomads and "Gypsies" in the laws, thereby linking them to criminality, and moved from restraining them to engaging in their potential rehabilitation. While this process had been developing in England (as well as other European countries), thousands of miles away, in India, a similar process of the criminalization of nomadic and semi-nomadic groups in India was in full swing by the seventeenth century.

\section{India: Precolonial and Colonial Law}

A look into India's legal system under colonial rule reveals similarities with the English systematic criminalization of groups. Postcolonial scholarship often argues that this process of criminalization was not indigenous to the Indian subcontinent but was imported and instituted by British colonists (Radhakrishna 2000, 2001, 2009). This view presents the effect of colonial legislation on India, and it implies that the criminalization of Indian communities was the consequence of British colonialist ruling in connection to Indian elites (Radhakrishna 2009). ${ }^{[12]}$

However, this perspective does not tell the full story of the criminalization of groups throughout Indian history. As Piliavsky (2015b) argues, "to be effective, stereotypes must have cultural purchase: they must

12 It is important to mention that the categorization of communities in India is intertwined deeply with the castist tradition that placed people by birth into different official (and economic) groups. This article does not delve into to this vast area of study, but acknowledges that a study of nomadism in relation to caste would further this project and give details about communities' categorization in India. 
be widely and readily recognized" (334). The British categorization (and criminalization) of certain groups did not occur on a blank Indian canvas; they were implemented within the context of a society with its own long-lasting and complex system of classifying "undesirables."

Following Gordon (1985), Freiteg (1991), Dundas (1995), Wagner (2007), and Piliavsky (2015a, b), I argue that identifying and categorizing entire nomadic groups as criminals has been a part of the Indian tradition dating back much farther than the advent of colonial influence: the judicial criminalization of communities, for example, dates hundreds of years before modern colonial India. Once colonialism ruled the subcontinent, it simply worked with the preexisting categories and power techniques to implement its own regime and systematize the criminalization of mobile communities.

Because the precolonial Indian economy depended on migratory labor, unsettled and semi-nomadic people were not seen as a possible threat at the time (Lucassen and Willems 2003). However, precolonial India identified entire groups as thieves, thugs, and criminals. Piliavsky (2015b) explains that even in "vedic accounts, like the kathās," entire tribes are described as "riteless, void of sense, inhuman," "frightful and terrible," "flesh-eating," "wine-drinking," "bird-hunting," "parrot-roasting," and "human-sacrificing predatory brutes" (Piliavsky 2015b, 330). While some of these tribes were nomadic, in precolonial India being itinerant was insufficient to criminalize a group or community. It is important to mention that, just like in England, in precolonial India the label of "nomadism" at times intersected with that of "criminal."

The belief that some people are born thieves or belong to a criminal group simply by their tradition appears in seminal Indian texts, such as The Laws of Manu, the law-giving treaty of approximately 1250 BCE. This text refers to those who are not confined to settled life, particularly to "robber tribes living outside the village" on "burial grounds," "on mountains and in groves," and that they wore "the garments of the dead," ate "their food from broken dishes," and "always wander[ed] from place to place” (Bühler 1886, 50-52, cited by Piliavsky 2015, 330). Law-giver Manu described "that forest tribes (dasyus) and the brutal, heretical, and low-living servants (sudras) were naturally drawn to forbidden occupations, like theft" (Bühler 1886, 4.61, 5.131, 9.225, 8.66, cited by Piliavsky 2015, 331). Criminals "who secretly prowl on this earth, cannot be restrained except by punishment" (IX 261-263: Buhler 1967, cited by Piliavsky 2015, 388-389). Majumdar (1961) states that these views made "crime as an inherited trait" (375). As a result, a large number of men and women who were both mobile and engaged in "forbidden" acts "were registered and stigmatized as criminals from birth" (ibid.). Moreover, as Radhakrishna (2001) argues: "it was a popular perception that these mobile people were vagrants, drifters, lazy, not given to any kind of 'disciplined' life, and therefore needed to be disciplined" (Radhakrishna 2001, cited by Rana 2011, 15). Categories and processes were thus created, intersecting the category of nomadism with that of criminality, and they organized and governed the Indian subcontinent before the British colonialist ruling.

It is nevertheless important to mention that even if criminalization of entire groups was practiced before British colonialism, India has been traditionally more tolerant to those who did not settle, allowing groups to live within its jungles and hills without seeing them as a threat to official power unless they committed additional acts of vagrancy. In other words, the precolonial preoccupation was mainly with those who displayed "habitual stealing of vast qualities of wealth, lack of concern for military strength 
used against them, contempt for divine and temporal power, and skill in burglary" (Piliavsky 2015, 334, citing a twelfth-century Jain text in Dundas 1995, 82).

The colonial powers became aware of these classifications, "absorbed many indigenous concepts, practices and institutions" (Piliavsky 2015, 324), and by essentializing them created a certain uniformity in the treatment of groups labeled as "criminal tribes," which now included itinerant ones. Thus, due to the underpinnings of colonial power, the criminalization of communities changed by the eighteenth century, and nomadic groups - who were not necessarily sharing any other characteristics - also became "criminals."

The pivotal legal act that criminalized many groups was the Criminal Tribes Act (CTA) of 1871. In addition to those deemed as being from "criminal communities," the Act included nomadism under "non-bailable offenses," and as a result officially linked criminality to nomadism within the Indian British Colonies:

If such tribe, gang or class has no fixed place of residence, the report shall state whether such tribe, gang or class follows any lawful occupation, and whether such occupation is in the opinion of the Local Government, the real occupation of such tribe, gang or class or a pretense of facilitating the commission of crimes (CTA 1871, Part II, 4: 122).

This legislation was justified on the basis of the colonial view of the Indian caste system:

The special feature of India is the caste system. As it is traders go by caste: a family of carpenters will be carpenters, a century or five centuries hence, if they last so long. Keeping this in mind the meaning of professional criminal is clear. It means a tribe whose ancestors were criminals from times immemorial, who are themselves destined by the usages of caste to commit crime and whose descendants will be offenders against the law, until the whole tribe is exterminated or accounted for in the manner of the Thugs. When a man tells you that he is an offender against the law, he has been so from the beginning, and will be so to the end, reform is impossible, for it is his trade, his caste, I may almost say his religion to commit crime (Hon'ble M. T.V. Stephens, member for Law and Order, cited by Kapadia 1952, 9).

A prior colonial ruling, the taxonomy of tribes, including nomadic ones, was not centralized or rigorously enforced. As a result, nomadic communities were able to move throughout vast territories and came under the state's scrutiny once they engaged in other punishable acts, such as thievery. The British, accustomed to exercising central authority, and aiming to settle those who moved, exported their model to the colonies. As a result, a community came under the radar of local authorities by simply being nomadic. The CTA recommended the creation of a report that shall "specify the place of residence in which such wandering tribe, gang or class is to be settled" (CTA 1871, Part II, 4). After this procedure was completed "the tribe, gang or class to which it relates ought to be declared criminal" (ibid., Article 5, 122), and authorities had to publicly declare that "such tribe, gang or class is a criminal tribe" (ibid.). Once this categorization became official, the members of these communities had to register with the Local Government, who in turn had the power to move or settle those who have "no fixed place of residence" (ibid., Article 13, 124) in reformatory settlements (ibid., Article 17, 124). 
The process of settling nomads was accompanied by a set of rules about conducting regular role-calls to prove their presence within "reformatory settlements." Moreover, just like in the case of nomads and those labeled "Gypsies" in Europe under the Vagrancy Act of 1744 (see above), under the CTA, those who broke these rules were severely punished with "rigorous imprisonment for a term which may extend to six months or with fine, or with whipping, or with all or with any two of those punishments" (ibid., Article 19, 126). Thus, colonialists created legislation that ensured dominance over entire groups, forced nomads to settle, and kept them visible under the eyes of the state, aiming to transform nomads into productive citizens for the state, and not for their own good:

The Criminal Tribes Act was used by the police administration for confining a number of CT members to various enterprises. (...) Giving employment to criminal tribes for their reformation (...) was obviously not the aim. The workers were needed only for two months, and no individual workers was to be employed for more than a month (Radhakrishna 2001/2008, 106).

The preoccupation with rehabilitation of those deemed as "criminals" was delegated to non-statist institutions, such as the Salvation Army, which were then entrusted with reforming nomads.

While the CTA went into effect in 1871, it is important to understand that given the great diversity across the subcontinent, the Act was not uniformly applied, and it underwent a long process until it was able to capture most of the communities living there. For example, in 1871 approximately 160 tribes were criminalized, mostly in Northern India. That number gradually increased, reaching three million people across India by 1947. The way in which a community was defined as a "criminal tribe" varied, based on what those in power deemed as undesirable. Among them, groups who were mobile and therefore difficult to control often fell under this legal regime. ${ }^{[13]}$

Lloyd (2014) posits that the British government assigned specific tribes' criminality through state administrators, not by transgression of the law. In doing so, the legal system implemented within British India was one based on "extraordinary" crime (Arnold 1986; Freitag 1991), which gave power to colonial authorities to control the population by arresting without warrant (CTA, Article 20, 126). As a result, like in England, individuals deemed as members of a criminal community lost their individuality. Importantly, this categorization was based on the simple "suspicion" of belonging to a group or community, not on factual proof. In effect, the CTA resembled British legislation in England, which stated that, "under Regulation XXII, section X, 1793, a person could be arrested on the suspicion that they were a 'notorious robber', a 'vagrant', or a 'disorderly and ill-disposed person" based on belonging to a community. Thus, through mere "suspicion," persons lost their individuality and fell under criminalized categories such as Dacoits, Cozauks, Thugs, and Buddeck. Like in the English example above, the existence of collective crimes is puzzling in the context of a colonial legal system that claimed the recognition of the individual as the main subject of the law.

13 Radhakrishna (2001) comments that this new assertion of power over the colonies was motivated by the erosion of the British state, which by the nineteenth century was struggling with "unemployment, strikes, economic depression, and a growing political radicalism" (3). 
The criminalization of groups and communities was not officially linked to being a "Gypsy," but Indian communities who were both criminalized and nomadic informally received the "Gypsy" label, a name adopted and reinforced even today in the twenty-first century. Thus, in India the "Gypsy" categorization informally arrived through British colonial underpinnings, labeling nomadic criminalized Indian communities as "Gypsy." If before the British colonial power gripped the Indian subcontinent, a community had to display their violence and propensity to theft in addition to their nomadism to be criminalized, now lack of permanent settlement alone was enough to be judicially deemed criminal, and therefore informally called "Gypsy."

Thus, the British rulers implemented similar power techniques in the Indian subcontinent to those already created back home and informally brought the "Gypsy" label to categorize undesirables. While groups might have migrated from India to Europe without a name attached to their community and ended up being labeled as "Gypsy", hundreds of years later the term "Gypsy" migrated back, this time without people. In the same manner Majumdar (1961) explains how different nomadic tribes of Northern India, such as Banthus, Sanshis, Karwals, Haburas, Tagu, Pakhiwara, Meena, and Harni, were thought to have a distinct modi operandi and "live[d] by anti-social activities, thievery, pilfering, dacoity and violence and became categorized as the 'Gypsy of India."'[14]

As a result, while the "Gypsy" label did not exist in precolonial India, it informally came into existence because the colonial categorization perceived groups on the subcontinent to be similar to those communities labeled "Gypsy" back home. The term "Gypsy" clearly was imported to India and superimposed on diverse populations who might not be otherwise related.

\section{The "Gypsy" in English Discourse: A Beauty and a Beast}

As mentioned above, laws are never created in a vacuum; they represent and operate in a larger system which inspires them and by which they are influenced. People or groups who are not settled have captured the imagination of (and often invoked fear among) settled communities for centuries. These tropes are visible in the literature of the time. Even though literary discourses do not have legal power, they have the power to create images and knowledge, which, in turn, is further reflected in the legal system.

In Europe, those labeled as "Gypsy" often had a double image. One can distinguish two complementary portrayals of nomads which still persist today: one romantic, praising their authentic lifestyle, and the other offensive, describing them as beasts. In the same vein as the laws, within England the main view since the seventeenth century was that "Gypsies" often were different, born as "others" (Mayall 1988). While they sometimes shared traits with other mobile individuals or groups (such as "travelers"),

14 In addition to criminal categorization, the British rulers used similar techniques of curtailing movements and punishment for those who disobeyed their organization. 
the true "pureblood Gypsy" - also called "Romany" - were said to live an idle life and camp in forests. They were thought to be racially different, and they were supposed to be easily distinguishable from other nomads because they were physically and temperamentally different, presumably because they came from Egypt. Mayall (1988) further tells us that "Gypsies" were usually described as "dark, supple, agile and handsome, possessing a temperament that was wild, fierce and defiant." Also, their "complexion was said to be swarthy, hair curly and black, eyes dark with a pearly lecture. The mode of dress was frequently portrayed as showy and colorful with headscarves, trinkets and droopy earrings in abundance" (Mayall 1988, 75-76).

According to Reynolds (2002), as early as the 1620s, the term "Gypsy":

Usually denoted people who travelled nomadically in groups, had dark skin, read fortunes, were performers, and acquired a reputation for immorality. The connotation or signified to the signifier Gypsy was paganism, sorcery, nomadism, profane sexuality, theatricality, deception, thievery, [linked to] the multifarious criminality, the 'gypsism' with which Gypsy is typically associated in literary texts, statues, legal records, and personal letters of the period (Mayall 1988, 23).

As early as 1596, Shakespeare also made references to "Gypsies" in A Midsummer Night's Dream, and in 1600, in As You Like It. The direct reference to the "Gypsy" as the "Egyptian charmer" who gave Othello's mother the well-known handkerchief appears in 1603's Othello, where a "Gypsy" woman was known for being able to almost read people's thoughts. One of the classical romances - a popular genre at that time - that gives an in-depth account of the life of the "Gypsy" is the eighteenth century memoir The Life and Adventures of Bampfylde Moore Carew. It describes the life of a settled Englishman who joined a "Gypsy" caravan and became nomadic as a result. Carew (1749) describes the "Gypsies" and "natural" nomads. Neither of them accepted the authority of the state, nor did they have "any envyings to torment them: they have no settled habitations, but move from place to place, as often as their convenience or pleasure requires it, which renders their life a perpetual scene of variety" (Carew 1749, 12). In the stereotypes of the time, those labeled as "Gypsies" were portrayed as powerful free spirits living outside society, defying its territorial boundaries, and enjoying their freedom.

But the fixed and idealistic image of freedom and defiance of the settled communities was often accompanied by a negative and hostile representation. According to Mayall (1988), the "Gypsies" were also described in literature as:

Closer to the animals than any other race known in Europe... the lowest possible level of existence. They were said to eat more like the beasts than men, subsisting on animals that had died of disease and the discarded refuse of settled society. ... [They] possessed animal traits of cunning, deceit and aggression (80).

Similarly, Mayhew (cited by Radhakrishna 2009) describes the "Gypsies" as "not yet formed to civilized habits." Furthermore, he claims that they "indulge their appetites when they could, restoring to plunder rather than submit to the discipline of steady work" (Radhakrishna 2009, 5). While not all those identified as "Gypsies" were nomadic, those who appeared mobile were seen as "fiercely proud and independent" 
and often ignored society's taboos. Mayall (1988) states in his analysis of the literature that the typecast of the "Gypsy" was presented as "free-living and free-loving, with a sexual appetite matched only by their wanderlust" and more than anything impossible to settle because "of the possession of black blood, or kalo ratt" (76). Again, the notion of inherited differences played an important role in the literary cliché: their wandering character was impossible to change, as it was "transmitted at birth" (ibid.). As a result of "Gypsies" being seen as different by birth, they were "Orientalized," treated differently, and perceived as somehow more "exotic" and thus separate from the accepted mainstream.

The tropes of the nomadic "Gypsy" in England between the seventeenth and eighteenth century extend beyond literature and into medical discourse. For example, in the 1800s, when local councils received complaints from residents about the new "Gypsy" encampments in their area, "some local medical practitioners testified that the camp smelt offensively," and their verdict was that "there was an accumulation of matter, no means of draining, and no water for flushing purposes ... the land was generally unhealthy and as a direct result there have been several cases of illness in the district" (Mayall 1988, 164). Medical discourses often relied on health concerns to create reasons that would justify the exclusion of nomads. Faced with the threat of possible diseases and death, states could implement rules and policies that affected mobile groups.

The malicious allegations of inborn nomadism in literature was further "extended and amplified by accusations of treachery, idleness, parasitism, heathenism and vice" (Mayall 1988, 80). Simultaneously being described as a beauty and a beast with untraceable or "Oriental" origins, living at the margin of the society, engaged in a mysterious nomadic lifestyle, the image of the wandering "Gypsy" was often linked to criminality and those who fell under this label were used as scapegoats. Thus, the stereotype of those categorized as "Gypsy" within the literature complemented and added to their criminalized legal profile.

If in the sixteenth century "the Gypsies" were considered to be in the same group as beggars and therefore were categorized as a social problem that the state needed to address via imprisonment, by the seventeenth century those labeled as "Gypsies" were presumed to lack Christian faith (Mayall 1988, 184). This both inspired and motivated various individuals and organizations "to remedy the state of affairs existing in camps of these savages living on the fringes of the settled society and be taught the word of God" (ibid.). Thus, at least a century before the state produced legislation that aimed to transform nomads and those identified as "Gypsies" into "docile bodies" (Foucault 1997/1995), the church was already concerned with their makeover and hoped to change them into members of the "flock." As Lucassen and Lucassen (1997) tell us, religious discourse saw the nomadic "Gypsies" as "people lacking a fixed abode and labeled as beggars or vagabonds were increasingly stigmatized as lazy and prone to criminal behavior" (Lucassen and Lucassen 1997, 227).

Not to be mistaken, in the medical, religious, and literary discourses from the seventeenth to the nineteenth century, two distinct categories are visible: "The Gypsy" and the nomad. But even though the two categories were separated, they also often overlapped. This blurred the distinction between nomads, criminals, and those labeled as "Gypsy," enabling the state to respond by increasing the institutionalization, incarceration, and possible rehabilitation of those deemed be a nuisance to its power. ${ }^{[15]}$

15 For more on the similar cases across Europe, see: Ocobock 2008. 
The two opposing clichés of the nomadic "Gypsy" as a romantic freedom-lover, away from the medium of settled life, and "the Gypsy" as a beast of prey, as dirty and criminal, assumed one common stereotype: "Gypsies" have a foreign origin. In all these texts, they were described as non-European, as having an Oriental origin, possibly coming from Egypt, or more likely from India. While not yet bearing the name "Gypsy" in Indian literature, the image of communities that were nomadic and lived at the margins of society were both praised for their courage and abhorred for their disruptive behavior.

\section{Thugs/Thieves, Nomads, and "Gypsies" in Indian Literature}

While in India the official criminalization of nomads through colonial power techniques is visible through the adoption of legal terms, their image in the literature is more abstruse. Different from Europe where a duplicitous image was formed around the "Gypsy" label, the Indian literature ${ }^{[16]}$ did not produce similar romantic literary tropes, but presented nomadism as one of the characteristics of the overall society. While not as numerous as the stories of "Gypsies" and mobile groups in Europe, stories dating back to the Indian Middle Ages portray wandering groups as thieves by trade, by nature, or by tradition. In "Rauhineya's Adventures," published in "Studies in the Honor in Maurice Bloomfield" by Bloomfield (1920), we learn that tribes like Rupiakhura or Silverhoof were described for centuries as "bold and rich thiefs," wandering "at night in various houses, and [taking] whatever pleased [their] fancy." These thieves were described as living at the margins of the cities and not tied to any settled communities (Piliavsky 2015a, 167). Similarly, Piliavsky (2015a, citing Johnson 1920) asserts that: "thieves were described as living in the mountains and inhabiting caves (16566). Like "the Gypsies" description in European literature, traditional roaming was depicted in the Indian literature of the seventeenth century as "wonderfully like animals" (Sangar 1967, 47 citing Tzuk Tr. I: 99, Text I: 48-49). It is therefore important to underline that those deemed as thieves neither belonged to one specific community nor were they always nomadic. These categories were separated, though at times they overlapped.

As seen above, nomadism was connected to criminality in India, with habitual robbers being seen as people who have no stable home, who do not live within larger sedentary communities, but "pour down in countless hordes from hill and plain for loot in bullock" (Piliavsky 2015b, 335 citing Beveridge 1921, 454). In a manner strikingly similar to the beastly image of the "Gypsies" in European literature, we are told by Fick (1920/1972) that in India some "races" were thought for hundreds of years to lead a

wandering life, feed mostly on animals (...) eating habits which ensured their long lasting impurity in the eyes of the mostly vegetarian settled population. Their lifestyle was unacceptable and inassimilable into the mainstream, and as a result even when they tried to set up their residences among the cultivated population, they [were] compelled to live in isolation outside of cities and maintain their livelihood by the meanest kinds of work (Fick 1920/1972, 315-316). 
For example, Fick argues that the Candalas were depicted as wandering from place to place, dressed in the garments of the dead, speaking a different language, and refusing to intimately connect with the rest of Indian society.

Traditionally, nomadic groups found in India were not labeled according to one name. But once British colonialism took root, the "Gypsy" label was informally superimposed on the existent categorization of diverse itinerant communities in a similar manner as they were described in England. The existent literary similarities further allowed colonists to assume transcontinental connections among itinerant communities and to criminalize nomads as they did back home.

\section{Conclusion}

Between the seventeenth and nineteenth century, nomadism and criminality became interlinked and associated with the term "Gypsy." This connection has been perpetuated over time, leaving behind a strong social, legal, and political legacy that labels those considered "Gypsy" as criminals and nomads in need of rehabilitation. This intersection was facilitated by a legal system intimately connected with other literary discourses. In England, from the seventeenth century onward we see a change from the past, with nomads coming under the strict scrutiny of the state, their movement and behavior often being criminalized. In precolonial India, nomads were better accommodated overall. Only when they exhibited additional traits (such as thievery) were nomads criminalized. However, once colonial rule gripped the Indian subcontinent, nomadic communities came under strict surveillance and became severely criminalized.

A similar image of those who move as criminals has been evident in other discourses, too. In England, literary discourses crystallized around the image of those labeled as "Gypsy," presenting them as both "beauty" and "beast." In India, this duplicitous image is not so clearly defined; instead, Indian literature that I surveyed for this article appears rich in tropes persistently describing nomads close to the European "beastly" image.

Thus, in India and England the label of "Gypsy" became associated with those who were thought to be both "nomads" and "criminals." This association persisted for centuries. For example, as recently as in 2010, communities such as the Yerukula were called by academics at Andhra University "a gypsy tribe, bearing an evil reputation as professional criminals" (Prakash and Sudhakar 2010, 21). In the west, the image of those labeled as "Gypsy" is still at times associated with criminality and nomadism. For example, on February 15, 2017, a news channel broadcasted: "authorities are looking for three crooks, considered part of a traveling Gypsy crime group, ... [who] are historically known for committing these types of distraction crimes, as well as violent crimes." ${ }^{[17]}$

17 Peter D’Oench. 2017. “Traveling Gypsy Crime Group’ Targeting Elderly in Hialeah.” CBS Miami, February 15. http://miami. cbslocal.com/2017/02/15/elderly-targeted-in-scams-by-traveling-gypsy-crime-group. 
The similarities between the criminal descriptions of mobile communities are remarkable in establishing the connection among targeted groups. These transcontinental resemblances stand as political evidence of how groups who did not want to be brought to the heel of the central government have been treated. This further highlights a specific form of political "othering," an all-too-common tendency to "Orientalize" those who are different, a collective inclination to define who is "other."

Further research is required, particularly in regard to investigating the intersection of notions such as "wanderer," "nomad," "thug," "Gypsy," and "criminal" - both in larger European and Asian texts. This could be supplemented by detailed theoretical discussions of the "Gypsy" categorization in South Asia in relation with colonial influence. While this article looks at how legal and literary discourses lead to the criminalization of those who move, it is important to further investigate how these discourses operated (or not) in practice. Further research on these practices would sharpen our understanding of how mechanisms of criminalization operate on the ground. Moreover, an in-depth investigation of the diverse and ever-changing categorization of those who move within the Indian subcontinent would reveal and expose the importance of caste and the ways in which various administrative power systems operated and instrumentalized this hierarchy. Unfortunately, these areas are beyond the scope of this article, which hopefully will stand as an incentive to further investigation on both English (and European) and Indian legal and literary discourses into how the label of "nomadism" has been historically linked to "criminality," and often associated to those labeled as "Gypsy." This intersection is a powerful social construction with a long, deep, and painful legacy, which continues to legitimize discrimination.

Today, across England and India, most of those who are labeled as "Gypsy" live at the margins of their societies, often with limited access to education, employment, and healthcare opportunities. While some have distinguished themselves socially and economically, many live in abject poverty, struggling to survive conditions such as the lack of running water and electricity. These conditions also are fueled by systematic persecutions, visible in numerous police acts. While identity is dialogical (i.e., created both by communities and outsiders), and communities on the ground have agency in defining the way they are seen by others, labeling communities as "criminal" leads to their marginalization. Without a commitment to expose and change legal and literary discourses, the legacy of in-born criminality is bound to lurk in the shadows for years to come.

\section{References}

Arnold, David. 1986. Police Power and Colonial Rule: Madras 1959-1947. New Delhi: Oxford University Press.

Barany, Zoltan. 2002. The East European Gypsies: Regime Change, Marginality and Ethnopolitics. New York: Cambridge University Press.

Berger, Peter L., and Thomas Luckmann. 1967. The Social Construction of Reality: A Treatise in the Sociology of Knowledge. Garden City, NY: Anchor.

Bloomfield, Maurice. 1920. Studies in the Honor of Maurice Bloomfield. New Haven: Yale University Press.

Conrad, Peter, and Joseph W. Schneider. 1992. Deviance and Medicalization: From Dadness to Sickness. Philadelphia: Temple University Press. 
Crowe, David M. 1994/1996. A History of the Gypsies of Eastern Europe and Russia. New York: St. Martin's Griffin.

Fick, Richard. 1972/1920. The Social Organization in North-East India in Buddha's Time. New Delhi: Indological Book House.

Fishman, James. 2007. Regulating the Poor and Encouraging Charity in Times of Crisis: The Poor Laws and the Statute of Charitable Uses. Pace Law Faculty Publications, Paper 406.

http://digitalcommons.pace.edu/lawfaculty/406

Fonseca, Isabel. 1995/2006. Bury Me Standing: The Gypsies and Their Journey. London: Vintage Books.

Foucault, Michel. 1977/1997. Power/Knowledge Selected Interviews and Other Writings. New York: Vintage Books. 1977/1995. Discipline and Punish: The Birth of the Prison. New York: Vintage Books.

- 1983. Michel Foucault on 'Disciplinary Society', Part 1. https://www.youtube.com/wath?v=Xk9ulS76PW8

_. 2001. "Nietzsche, Genealogy, History." In Nietzsche, edited by John Richardson and Brian Leiter, 139-164. New York: Oxford University Press.

Freitag, Sandria. 1991. "Crime in the Social Order of Colonial North India." Modern Asian Studies 25 (2): 227-261. http://www.jstor.org/stable/312511.

Kapadia K. M. 1952. “The Criminal Tribes of India” in Sociological Bulletin, Vol 2: 99-125. https://doi.org/10.1177/0038022919520203

Lambert, John. 1868. Vagrancy Laws and Vagrants: A Lecture. Salisbury: Brown \& Co; London: Canal.

Lloyd, Tom. 2014. "Thuggee" and the Margins of the State in Early Nineteenth-Century Colonial India. http://www.csas.ed.ac.uk/mutiny/confpapers/Lloyd-Paper.pdf

Lucassen, Jan, and Leo Lucassen, eds. 1997. Migration, Migration History, History: Old Paradigms and New Perspectives. Berne: Peter Lang AG, European Academic Publishers.

Lucassen, Leo and Wim Willems. 2003. The Weakness of Well Ordered Societies. Gypsies in Western Europe, the Ottoman Empire and India 1400-1914; abridged version in Review 26 (3): 283-313. http://exclusion.pep.uoi.gr/ROMA/synedria/3/Lucassen.pdf

- 2012. Living in the City: Urban Institutions in the Low Countries, 1200-2010. New York: Routledge.

Majumdar, Dhirendra Nath. 1961. Races and Cultures of India. Bombay: Asia Publishing House.

Matras, Yaron. 2014. I Met Lucky People: The Story of the Romani Gypsies. London: Penguin, Random House U.K.

Mayall, David. 1988. Gypsy - Travellers in Nineteenth Century Society. Cambridge: Cambridge University Press.

McVeigh, Rory. 1997. “Theorising Sedentarism: The Roots of Anti-Nomadism.” In Gypsy Politics and Traveller Identity, edited by Thomas Acton, 7-25. Hatfield: University of Hertfordshire Press.

Morgan, John Emrys. 2016. "Counterfeit Egyptians': The Construction and Implementation of a Criminal Identity in Early Modern England.” Romani Studies (26) 2: 105-128. https://doi.org/10.3828/rs.2016.7

Ocobock, Paul. 2008. "Introduction: Vagrancy and Homelessness in Global and Historical Perspective." In Cast Out: Vagrancy and Homelessness in Global and Historical Perspective, edited by Paul Ocobock and A.L. Beier 1-34. Athens: Ohio University Press. https://doi.org/10.2307/j.ctt1rfsq2g.4

Pickering, Dandby. 1763. The Statutes at Large, from the Thirty-second Year of King Henry VIII. to the Seventh Year of King Edward VI. inclusive. (Vol. 5). Cambridge: J. Bentham. 
Piliavsky, Anastasia. 2015a. "Patronage and Community in a Society of Thieves." Contributions to Indian Sociology 49 (2): 135-161.

-2015b. “The 'Criminal Tribe' in India before the British." Comparative Studies in Society and History 57 (2): 323-354.

Prakash, Deva, and Godi Sudhakar. 2010. "Palmar C- Line Variation Among Yerukula, a Nomadic Tribe of South India." Antrocom 6 (1): 1-24. http://www.antrocom.net/upload/sub/antrocom/060110/04-Antrocom.pdf

Rana, Subir. 2011. Nomadism, Ambulation and the "Empire": Contextualising the Criminal Tribes Act XXVII of 1871. http://www2.hu-berlin.de/transcience/Vol2_Issue2_2011_1_22.pdf

Radhakrishna, Meena. 2000. “Colonial Construction of a 'Criminal' Tribe: Yerukulas of Madras Presidency.” Economic and Political Weekly 35 (28/29): 2553-563. http://www.jstor.org/stable/4409505

-2001. Dishonoured by History: Criminal Tribes \& British Colonial History. Hyderabad: Orient Longman.

- 2009. "Laws of Metamorphosis: From Nomad to Offender." In Challenging the Rule(s) of Law: Colonialism, Criminology and Human Rights in India, edited by Kalpana Kannabiran and Ranbir Singh, 3-28. Thousand Oaks: Sage Publication. http://dx.doi.org/10.4135/9788132100270.n1

Reynolds, Brian. 2002. Becoming Criminal: Transversal Performance and Cultural Dissidence in Early Modern England. Baltimore and London: Johns Hopkins University Press.

Sangar, Satya Prakash. 1967. Crime and Punishment in Mughal India. Delhi: Sterling Publishers.

Shakespeare, William. 1992. A Midsummer Night's Dream. New York: Dover Publications.

—. 2012. As You Like It. Dover Thrift Editions. Kindle Edition.

-2012. Othello, Amazon Digital Services. Inc. Kindle Edition.

Shashi, Shyam Singh. 1990. Roma: The Gypsy World. Delhi: Sundeep Prakashan.

Shields, Audrey Carr. 1993. Gypsy Stereotypes in Victorian Literature. PhD dissertation, New York University.

Surdu, Mihai. 2016. Those Who Count: Expert Practices of Roma Classification. Budapest: Central European University Press.

Taylor, Charles. 1994. “The Politics of Recognition.” In Multiculturalism: Examining the Politics of Recognition, edited by Amy Guttman, 25-73. Princeton, NJ: Princeton University Press.

Taylor, Stephanie. 2015. "Identity Construction." In The International Encyclopedia of Language and Social Interaction, edited by Karen Tracy, 1-9. Hoboken, J: John Wiley \& Sons, Inc. https://doi.org/10.1002/9781118611463.wbielsi099.

Wagner, Kim A. 2007. Thuggee: Banditry and the British in Early Nineteenth-Century India. London: Palgrave Macmillan. 